\title{
Recent storm and tsunami coarse-clast deposit characteristics, southeast Hawaili
}

\author{
Bruce M. Richmond ${ }^{\mathrm{a}, *}{ }^{*}$, Steve Watt ${ }^{\mathrm{a}}$, Mark Buckley ${ }^{\mathrm{a}}$, Bruce E. Jaffe ${ }^{\mathrm{a}}$, Guy Gelfenbaum ${ }^{\mathrm{b}}$, Robert A. Morton ${ }^{\mathrm{c}}$ \\ a U.S. Geological Survey, Pacific Science Center, 400 Natural Bridges Drive, Santa Cruz, CA, 95060, United States \\ b U.S. Geological Survey, 345 Middlefield Rd., MS999, Menlo Park, CA, 94025, United States \\ c U.S. Geological Survey, 10100 Burnet Rd., Bldg 130, Austin, TX, 78750, United States
}

\section{A R T I C L E I N F O}

\section{Article history:}

Received 3 February 2010

Received in revised form 21 July 2010

Accepted 3 August 2010

Available online 12 August 2010

\section{Keywords:}

tsunami deposits

storm deposits

gravel

boulder transport

Hawai'i

\begin{abstract}
A B S T R A C T
Deposits formed by extreme waves can be useful in elucidating the type and characteristics of the depositional event. The study area on the southeast coast of the island of Hawaici is characterized by the presence of geologically young basalts of known age that are mantled by recent wave-derived sedimentary deposits. The area has been impacted by large swells, storms and tsunamis over the last century, and in combination with known substrate ages makes this an ideal location to study recent deposits produced by such events.

Three distinct coarse-clast deposit assemblages can be recognized based on clast size, composition, angularity, orientation, packing, elevation and inland distance of the deposit. These deposits are characterized as one of three types. 1) Gravel fields of isolated clasts, primarily boulder-size material, and scattered pockets of concentrated sand and gravel in topographic lows. 2) Shore-parallel and cuspate ridges composed mostly of rounded basalt gravel and sand with small amounts of carbonate detritus. The ridges range in height from about 1 to $3 \mathrm{~m}$ and are 10s of $\mathrm{m}$ wide. 3 ) Cliff-top deposits of scattered angular and subangular clasts along sea cliffs that are generally greater than $5 \mathrm{~m}$ elevation. The gravel fields are primarily of tsunami origin from either the 1975 Kalapana event, or a combination of the 1975 tsunami, and 1868 tsunami or earlier events. The ridge deposits are presently active and sediment continues to be added during high wave events. The cliff-top deposits contain evidence of deposition by both tsunami and storm processes and require further investigation.
\end{abstract}

Published by Elsevier B.V.

\section{Introduction}

Sedimentary deposits produced by extreme-wave events, such as storms and tsunamis, have the potential to provide valuable information on the magnitude and frequency of marine inundation, wave characteristics, and hazard risk along vulnerable coasts. Because there are many coasts that can be impacted by both large storm waves and tsunamis, it is important to develop criteria to distinguish between the two types of events. Differences in the severity and frequency of impacts between the two phenomena necessitate an understanding of the potential hazard risks. There is a growing body of literature devoted to extreme wave deposits (e.g. Morton et al., 2007; Switzer and Jones, 2008; Goto et al., 2009), but in general there is little agreement as to what constitutes diagnostic criteria to distinguish storm from tsunami deposits, this is especially the case in coarse-clast sediments and boulders (e.g. Switzer and Burston, 2010). For example, on the island of Bonaire in the Netherlands Antilles, shore-parallel ridges of gravel-rich, reef-derived sediment have been ascribed to both predominantly tsunami origin (Scheffers, 2005; Scheffers et al., 2009) and predomi-

\footnotetext{
* Corresponding author. Tel.: +1 831427 4731; fax: +1 8314274748

E-mail address: brichmond@usgs.gov (B.M. Richmond).
}

nantly storm-wave origin (Morton et al., 2008). In this case there is no historical record of tsunamis impacting Bonaire and several recent hurricanes that tracked near the island did not contribute significant sediment to ridge complex development which has lead to the conflicting interpretations of the deposits.

This paper examines primarily coarse-clast deposits that have formed recently from extreme waves of both tsunami and storm origin along the southeast coast of the island of Hawaii. The study area offers a rare opportunity to observe coarse-clast deposits from recent storms and tsunamis on land surfaces of known age, which can aid in the interpretation of the origin of the deposit.

\section{Regional setting}

\subsection{Geology and geomorphology of the study area}

The island of Hawaii is a young volcanic island formed by the coalescence of five subaerial volcanoes, three of which have been historically active. The study area on the southeast coast (Fig. 1) is underlain by volcanic deposits of the youngest Hawaiian volcano, Kilauea, currently in the shield forming stage. It began erupting about $300,000-600,000$ years ago and has been erupting almost continuously ever since (Holcomb, 1987). Kilauea has erupted from three main areas, 


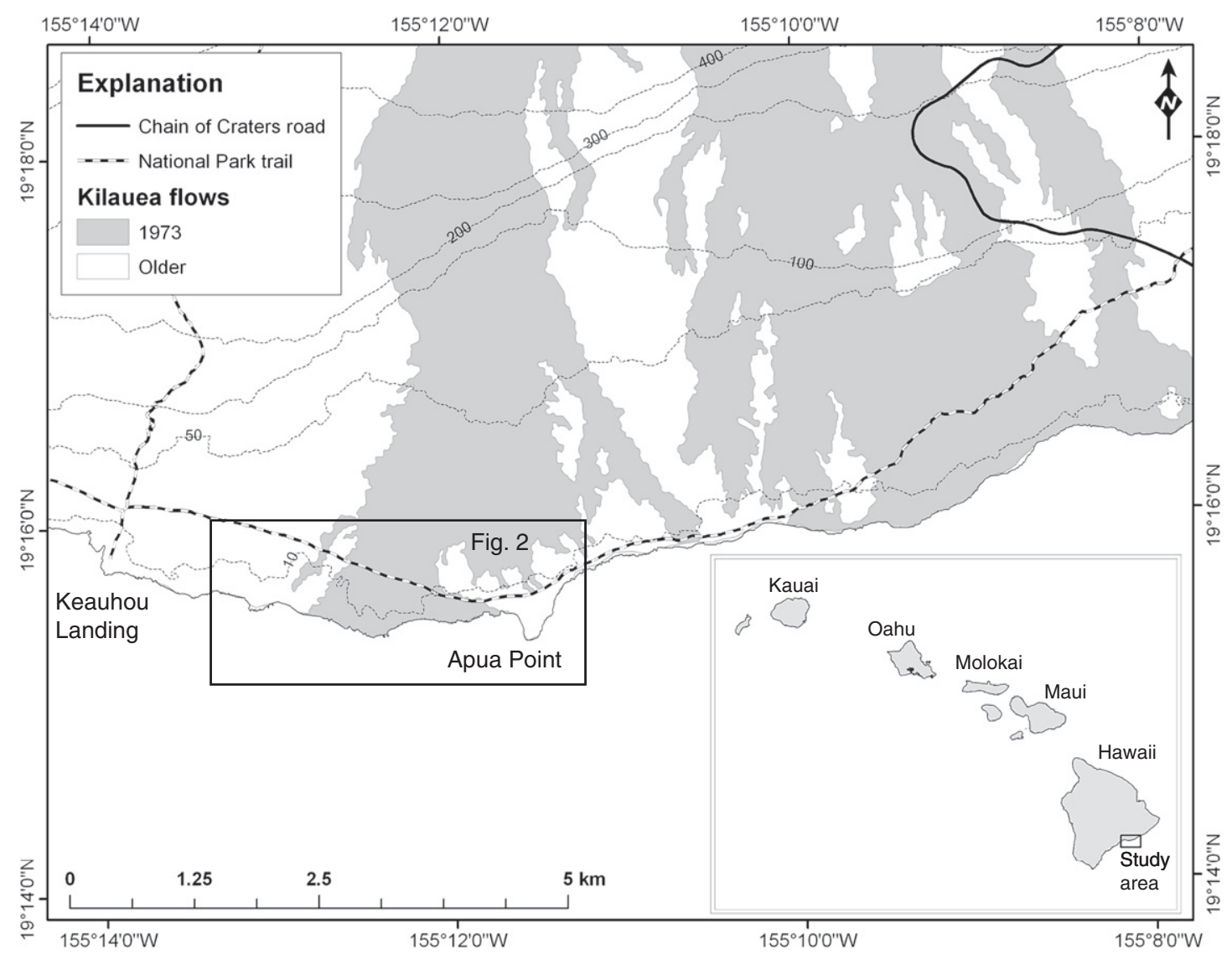

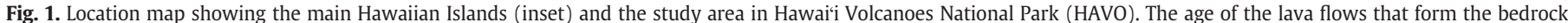
surface are from Holcomb, 1987.

its summit and two rift zones. Most Kilauea eruptions are non-explosive, sending lava flows slowly down slope. The study site encompasses bedrock of both recent and historical basalts (Wolfe and Morris, 1996; Sherrod et al., 2007) that consist of the 1973 Mauna Ulu Flows, the Keauhou Flows ( 500-350 years old) and the Kipuka Nene Flows ( 1500-1000 years old; Holcomb, 1987). In addition to volcanic activity, Kilauea has undergone repeated inflation and deflation periods with subsidence of more than $200 \mathrm{~cm}$ near the summit while the adjacent south flank has risen more than $50 \mathrm{~cm}$ (Delaney et al., 1998). Kilauea has continued to spread along its rift system, accompanied by displacement and subsidence near the summit and south flank uplift and seaward slip (Owen et al., 2000).

Our area of detailed study in Hawaici Volcanoes National Park (HAVO) extends from Apua Point to Keauhou Landing (Fig. 1), a segment of coast that forms the seaward margin of several broad, gently seaward-sloping, lava deltas that abruptly end at the coast with sea cliffs interspersed with small pocket beaches. The underlying basalt platform that forms the coastal plain rises in elevation from sea level to about $90-120 \mathrm{~m}$ where it intersects the base of a steep escarpment. Width of the platform in the study area ranges from about $1750 \mathrm{~m}$ at Keauhou Landing to $4150 \mathrm{~m}$ at Apua Point. There are both roughly shore-parallel and shore-normal low-relief ridges throughout the area. Some of these features approach $10 \mathrm{~m}$ in overall relief and appear to be related to lava flow and subsequent cooling processes.

Most of the area is underlain by relatively smooth pahoehoe lava flows, although there are some areas of rough a'a flows. The relatively smooth pahoehoe surface is often interrupted by elliptical, domed volcanic structures called tumuli. Tumuli are created in slow-moving lava and are commonly $10 \mathrm{~s}$ of $\mathrm{m}$ in diameter and extend 2-6 $\mathrm{m}$ above the surrounding lava. Fractures and cracks are common within the tumuli dome and are a local source of coarse sediment. Coastal vegetation varies from very sparse on recent flows to thin and patchy on the older flows. Land islands with vegetation and weathered lava (kipukas) occur where younger flows have completely surrounded older lava. This irregular landscape creates topographic lows that serve as suitable sediment traps separated by elevated areas of low sediment deposition. Apart from local downslope runoff there is no network of surface streams that would influence the distribution of sediment clasts. Finer sediment could be reworked during heavy rain and high wind events. Sediment at the coast is derived either from the cliff face, immediate offshore zone, or more rarely from gravity-driven deposition from upslope.

\subsection{Recent tsunami history}

The coasts of the Hawaiian Islands are subject to the impacts of both storm waves and tsunamis. Because of its location in the central North Pacific, the Hawaiian Islands receive trans-oceanic tsunamis from locations around the Pacific Rim as well as locally generated tsunami. Using confirmed published sources Walker (1994) noted 22 Pacific basin tsunamis with runup elevations greater than $1 \mathrm{~m}$ in the islands of Hawai'i since 1812. The highest tsunami runup elevation reported by Lander and Lockridge (1989) was $16.4 \mathrm{~m}$ at Waikolu Valley, north Molokai as a result of the 1946 Aleutian Islands earthquake event. Tsunami runup on the island of Hawaici from the 1946 tsunami ranged from $2 \mathrm{~m}$ at Honaunau on the west coast to nearly $17 \mathrm{~m}$ at Pololu Valley on the northeast coast (Lander and Lockridge, 1989; Dudley and Lee, 1998. The last large tsunami of distant origin to strongly affect the Hawaiian Islands was generated by a great (magnitude 9.5) earthquake in Chile in 1960 that caused extensive damage in the Hilo, Hawai'i area (Dudley and Lee, 1998). The recent February 27, 2010 magnitude 8.8 earthquake in Chile created a Pacific-wide tsunami, however the tsunami in Hawai'i was 
small with a highest measured amplitude on the island of Hawaici of $0.86 \mathrm{~m}$ at Hilo (www.ngdc.noaa.gov/hazard/tsu/shtml; last accessed on June 15,2010$)$.

In addition to ocean-wide events, the Hawaiian Islands are subject to locally generated tsunamis from earthquakes and/or landslides. Twenty-three tsunamis with measurable runup and a local source have been recorded for Hawaii since 1840 as documented in the NOAA World Data Center (WDC) Historical Tsunami Database at the National Geophysical Data Center (NGDC; available on-line at: http:// www.ngdc.noaa.gov/hazard/tsu_db.shtml, last accessed on 11/21/ 08). The maximum runup height from the NGDC data base is $14.3 \mathrm{~m}$ at Keauhou Landing (southeast Hawaici) as a result of the locally generated tsunami created by the 1975 Kalapana earthquake (M 7.2) which was characterized by rapid coastal subsidence and associated submarine slump (Day et al., 2005; Tilling et al., 1976). This was the largest locally generated tsunami to impact Hawaici in the 20th century and it produced deposits as much as $320 \mathrm{~m}$ inland and up to $10 \mathrm{~m}$ above sea level as reported by Goff et al. (2006). A similar locally generated tsunami was caused by an earthquake of magnitude 7.5-8.1 in 1868 on the south flank of Mauna Loa. Multiple waves caused maximum runup elevations of almost $14 \mathrm{~m}$ near Keauhou Landing (NGDC; Dudley and Lee, 1998). Deposits from the 1975, 1868, and possible earlier unnamed tsunami events are studied here. Ancient megatsunami deposits have been described from the flanks of Kohala volcano on northwest Hawai'i (McMurtry et al., 2004), but no such deposits have been identified in our study area.

\subsection{Storms in Hawai $i$}

Hawaii's shorelines receive high waves that are generated by distant storms in the Northern and Southern Hemisphere, and by tropical storms, hurricanes, and winter Kona storms that enter Hawaiian waters. The study area in southeast Hawaici is exposed to waves arriving between approximately $60^{\circ}$ and $200^{\circ}$ that encompass waves from southern swell, easterly tradewinds, and the occasional Kona storm or passing hurricane.

Table 1 presents the annual maximum significant wave height, period, and direction for the $60^{\circ}-200^{\circ}$ wave window for a twentyyear period from 1984 to 2004. The wave analysis combines

\section{Table 1}

The annual maximum significant wave height and associated period and direction for southeast Hawai'i during the twenty-year period from 1984 to 2004.

\begin{tabular}{|c|c|c|c|c|c|}
\hline & Hs (m) & $\mathrm{Tp}(\mathrm{sec})$ & Direction $^{\circ}$ & Year & Month/Day \\
\hline & 4.4 & 14.2 & 069 & 1984 & $11 / 19$ \\
\hline & 4.9 & 9.5 & 068 & 1985 & $3 / 26$ \\
\hline & 10.6 & 13.6 & 066 & 1986 & $7 / 22$ \\
\hline & 4.0 & 9.0 & 073 & 1987 & $11 / 30$ \\
\hline & 5.4 & 11.3 & 064 & 1988 & $12 / 31$ \\
\hline & 6.3 & 12.3 & 084 & 1989 & $1 / 10$ \\
\hline & 6.0 & 9.0 & 071 & 1990 & $9 / 17$ \\
\hline & 4.5 & 9.3 & 079 & 1991 & $3 / 13$ \\
\hline & 4.9 & 12.2 & 103 & 1992 & $7 / 25$ \\
\hline & 4.8 & 12.5 & 072 & 1993 & $8 / 16$ \\
\hline & 5.4 & 11.0 & 072 & 1994 & $11 / 19$ \\
\hline & 5.5 & 10.3 & 065 & 1995 & $4 / 17$ \\
\hline & 4.4 & 9.9 & 064 & 1996 & $11 / 28$ \\
\hline & 4.7 & 12.0 & 071 & 1997 & $2 / 27$ \\
\hline & 6.7 & 12.3 & 068 & 1998 & $12 / 5$ \\
\hline & 5.4 & 12.9 & 078 & 1999 & $8 / 15$ \\
\hline & 4.5 & 10.5 & 068 & 2000 & $1 / 9$ \\
\hline & 6.5 & 11.5 & 060 & 2001 & $12 / 13$ \\
\hline & 4.4 & 9.6 & 063 & 2002 & $12 / 29$ \\
\hline & 4.9 & 9.5 & 078 & 2003 & $11 / 11$ \\
\hline & 4.5 & 9.3 & 064 & 2004 & $12 / 5$ \\
\hline Max & 10.6 & 13.6 & 103 & & \\
\hline Min & 4.0 & 9.0 & 060 & & \\
\hline Average & 5.4 & 10.9 & 072 & & \\
\hline
\end{tabular}

overlapping buoy and hindcast data to derive directional wave height and period information. Wave height and period data are from the NDBC Hawai'i offshore non-directional wave buoy 51004 , located in about $5000 \mathrm{~m}$ of water $350 \mathrm{~km}$ to the southeast of the study site (NOAA National Data Buoy Center, last accessed on 09/18/2009: http://www.ndbc.noaa.gov/station_page.php?station=51004), and wave direction is derived from wave hindcast data provided by the U.S. Army Corps of Engineers Wave Information Studies (WIS) program (Station 51004, last accessed on 1/15/10: http://frf.usace. army.mil/cgi-bin/wis/pac/pac_main.html). The annual maximum significant wave height for the period ranges from $4.0 \mathrm{~m}$ to $10.6 \mathrm{~m}$; with an average annual maximum significant wave height of $5.4 \mathrm{~m}$. Dominate wave period range from 9 to $14 \mathrm{~s}$, with an average dominant period of $11 \mathrm{~s}$. Predominate wave direction is easterly as a result of exposure to the consistent northeasterly tradewinds. On average there are 184 days per year with significant wave heights greater than $2 \mathrm{~m}$, 45 days per year with significant wave heights greater than $3 \mathrm{~m}$, and 8 days a year with significant wave heights greater than $4 \mathrm{~m}$. The maximum significant wave height for the twenty-year period was generated by Hurricane Estelle on July 22, $1986\left(\mathrm{Hs}=10.6 \mathrm{~m}, \mathrm{Tp}=13.6 \mathrm{~s}, \mathrm{Dir}=66^{\circ}\right)$. Hurricane Estelle passed to the south of the study area as a Category 3 Hurricane and generated $6 \mathrm{~m}$ waves at the coast that coincided with spring high tides and resulted in beach evacuations along the southeast coast of Hawaici (National Weather Service, Central Pacific Hurricane Center: http:// www.prh.noaa.gov/cphc/summaries/1986.php; last accessed 1/29/ 2010). Historical storms that impacted Hawaici but are not in the NGDC buoy database include: Hurricanes 'Iwa (1982), Dot (1959), Nina (1957) and a large unnamed event in 1871.

During field work in August of 2008, a moderate southerly swell ( $\mathrm{Hs}=2.4 \mathrm{~m} ; \mathrm{Tp}=15 \mathrm{~s}$ ) produced waves at the shoreline that were observed to transport and rework sediment over the cliff tops and ridge crests in most of the study area. Events of this magnitude occur on numerous occasions throughout the year and are responsible for sediment delivery and reworking at the coast. Larger events are capable of transporting more sediment and larger clasts. Reworking of sediment includes rounding of boulders in coastal ridges.

\section{Methods}

The focus of our field work was to document sediment characteristics and deposit morphology in a coastal area impacted by both storms and tsunamis. Coastal deposits in the Apua Point to Keauhou Landing area of HAVO (Fig. 1) were examined in the field during August of 2007 and 2008. Data collected include high-resolution aerial kite camera color photographs, topographic profiles and photographic transects, sediment samples, and general field observations. In addition, selected individual boulder measurements of the a,b,c-axis and orientation were collected. All digital data were integrated into a GIS database for further analyses. After the field surveys were completed, airborne lidar data became available from the Federal Emergency and Management Agency (FEMA) and was used to construct a high-resolution digital elevation model (DEM) of the study area.

A specially designed kite and digital camera system was developed to obtain color aerial photographs at several locations within the study area (Fig. 2). The system consisted of one of several kites, depending upon wind conditions, a small digital camera capable of remote operation. Ground control points established by handheld GPS units (Garmin GPSmap 76CS; $\pm 2 \mathrm{~m}$ time-averaged positional accuracy) were used to georeference images. Aerial kite camera images were collected along both shore-parallel and shore-normal transects. Shore-normal transects extended from the shoreline to approximately $400 \mathrm{~m}$ inland. The camera was flown at a height of $\sim 75 \mathrm{~m}$ above ground. Topographic profiles were collected using an Impulse LR laser range finder (distance and elevation measurements) 


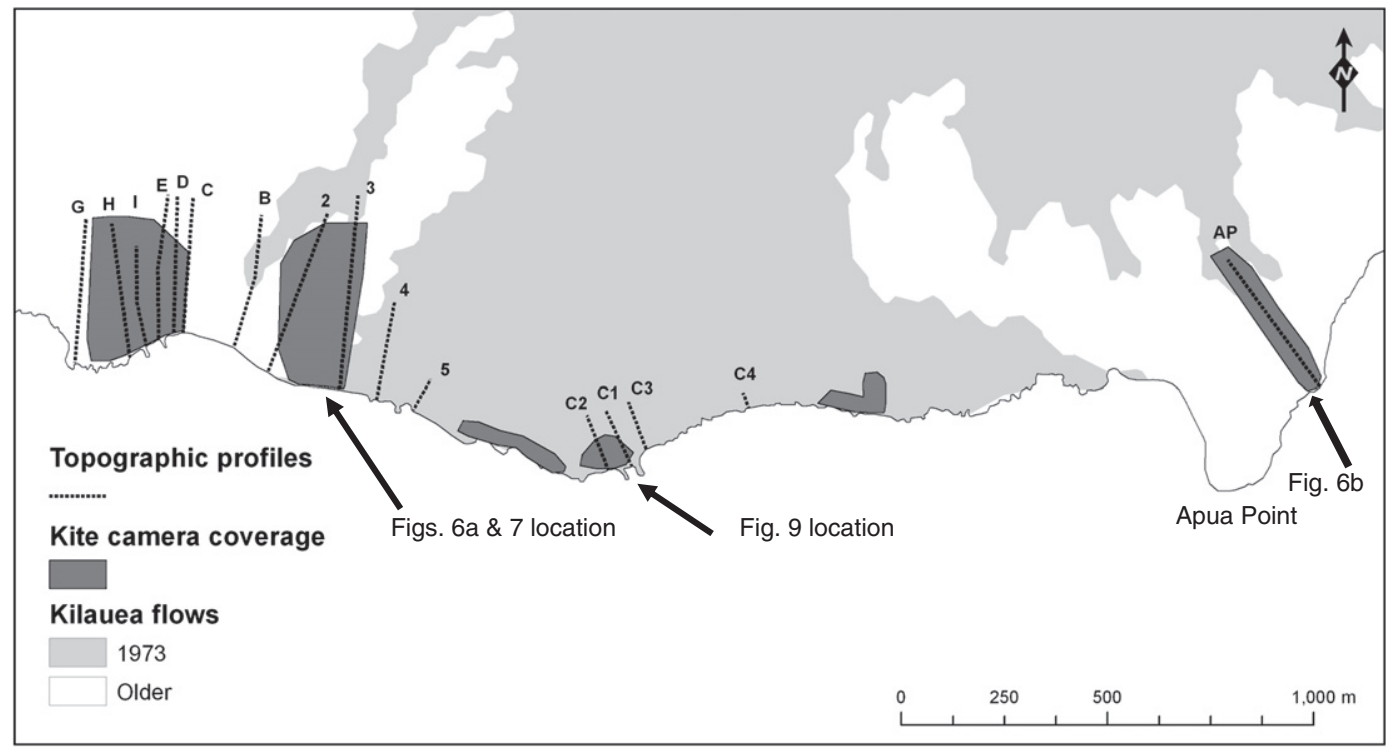

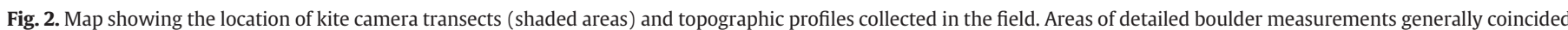
with kite camera coverage.

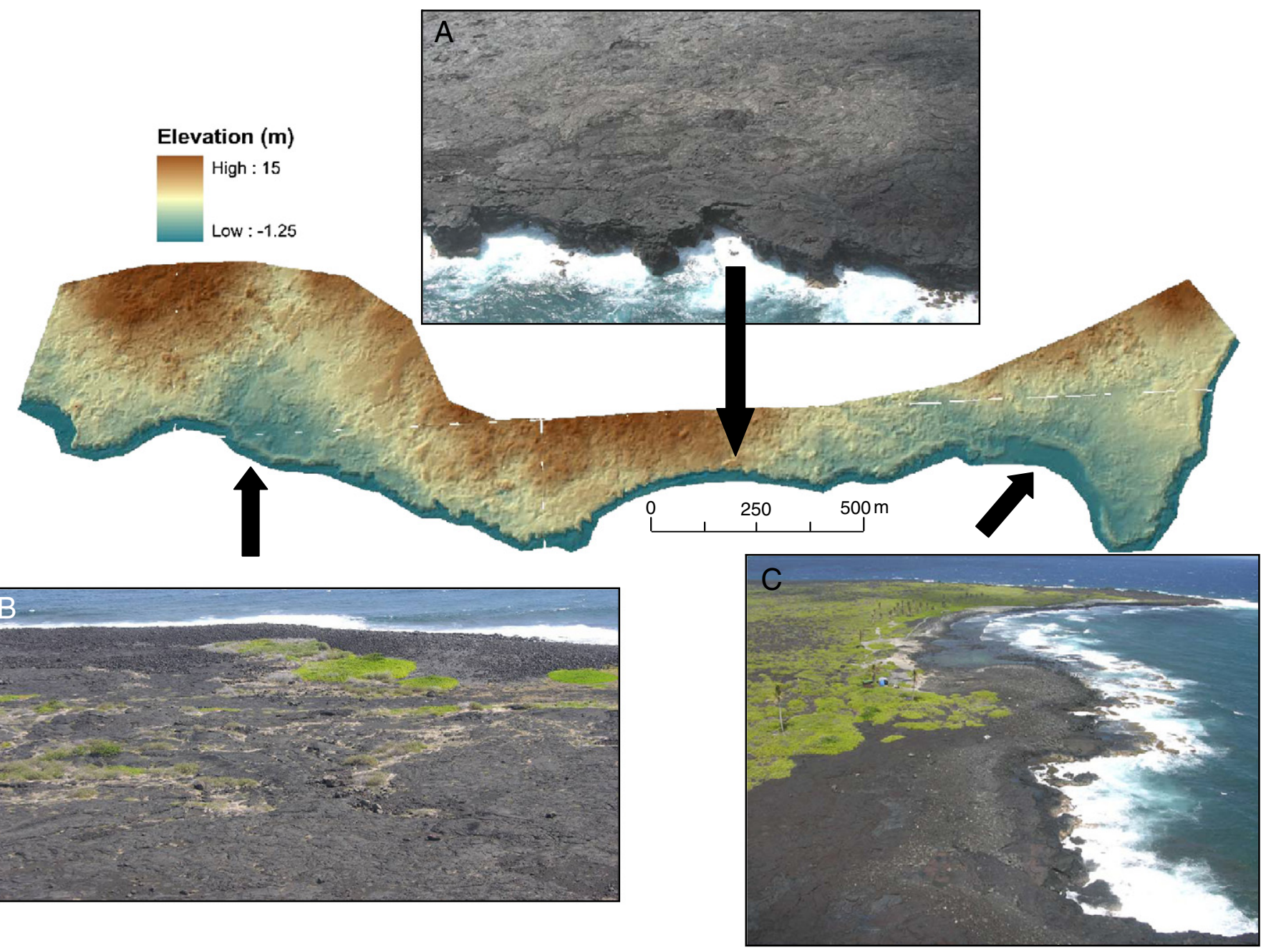

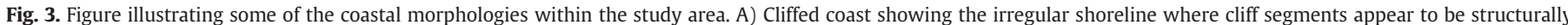

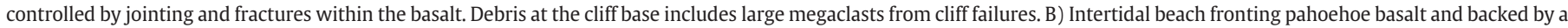

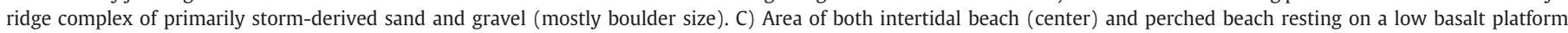
(foreground). Oblique aerial photography was collected in August 2007. Base image is a shaded relief lidar DEM from data collected in 2007 (lidar data courtesy of FEMA). 
and Garmin GPSmap 76CS (geographic location). Local approximate sea level at the time of profiling was used to establish the vertical datum. Boulder dimensions and the orientation of the longest axis (a-axis) were measured in the field for all boulders except those composing the shore-parallel ridge deposits that were measured from georeferenced kite camera images and coordinate geometry tools in GIS. Boulder locations were mapped in two ways: 1) using a Garmin GPSmap 76CS and, 2) by marking boulders on georeferenced kite camera images in GIS.

\section{Results}

\subsection{Coastal geomorphology}

The underlying basalt platform that forms the coastal plain rises in elevation from sea level to about $90-120 \mathrm{~m}$ where it intersects the base of a steep escarpment. Width of the platform in the study area ranges from about $1750 \mathrm{~m}$ at Keauhou Landing to $4150 \mathrm{~m}$ at Apua Point. Coastal morphologies occurring along the study area coast include cliffs, low basalt terrace or platform with or without a perched beach, and intertidal beach (Fig. 3).

The type of shoreline present is controlled by a combination factors such as: basalt thickness that determines the elevation at the coast, neotectonics and recent uplift and/or subsidence history, rock lithology and strength which controls rate of erosion, and exposure to waves. For example, high cliffs occur in exposed areas of thick basalt where debris is rapidly removed from the base of failing cliffs. Beaches occur within low-lying embayments or perched upon low basalt platforms.

Most of the study area coastline is cliffed which varies in elevation from low basalt terrace/platform a few meters high to vertical cliff faces up to $\sim 8 \mathrm{~m}$ in height. There is a wide range of cliff face morphology from a simple near-vertical cliff face to stepped faces composed of multiple terraces. The cliffs occur at the exposed seaward edge of young basalt that appears to be undergoing relatively rapid erosion primarily from wave attack. Honeycomb weathering patterns are often observed in the basalt along the upper seaward edge of the cliff. In some localities, instead of a vertical cliff the basalt forms a steeply sloping ramp-like surface.

Cliff failure commonly appears to occur as block failure that varies from boulder $(>25 \mathrm{~cm})$ to megablock $(10 \mathrm{~s}$ of $\mathrm{m})$ size failures. Failure pattern appears to be strongly controlled by rock and joint parameters such as rock strength, joint spacing and orientation, and depth of jointing within the rock mass. Joints extending through multiple basalt layers probably enhance failure of the entire cliff face, whereas joints confined to individual basalt layers most-likely result in the stepped failures. The nearshore zone seaward of the cliffs is commonly littered with rounded to slightly rounded large blocks that were derived from the superjacent cliffs. The intertidal zone is marked by a pinkish bio-encrustation of the rock surface.

The high cliffs typically grade laterally into low basalt terraces that are often mantled by perched beach deposits. The terraces are fronted

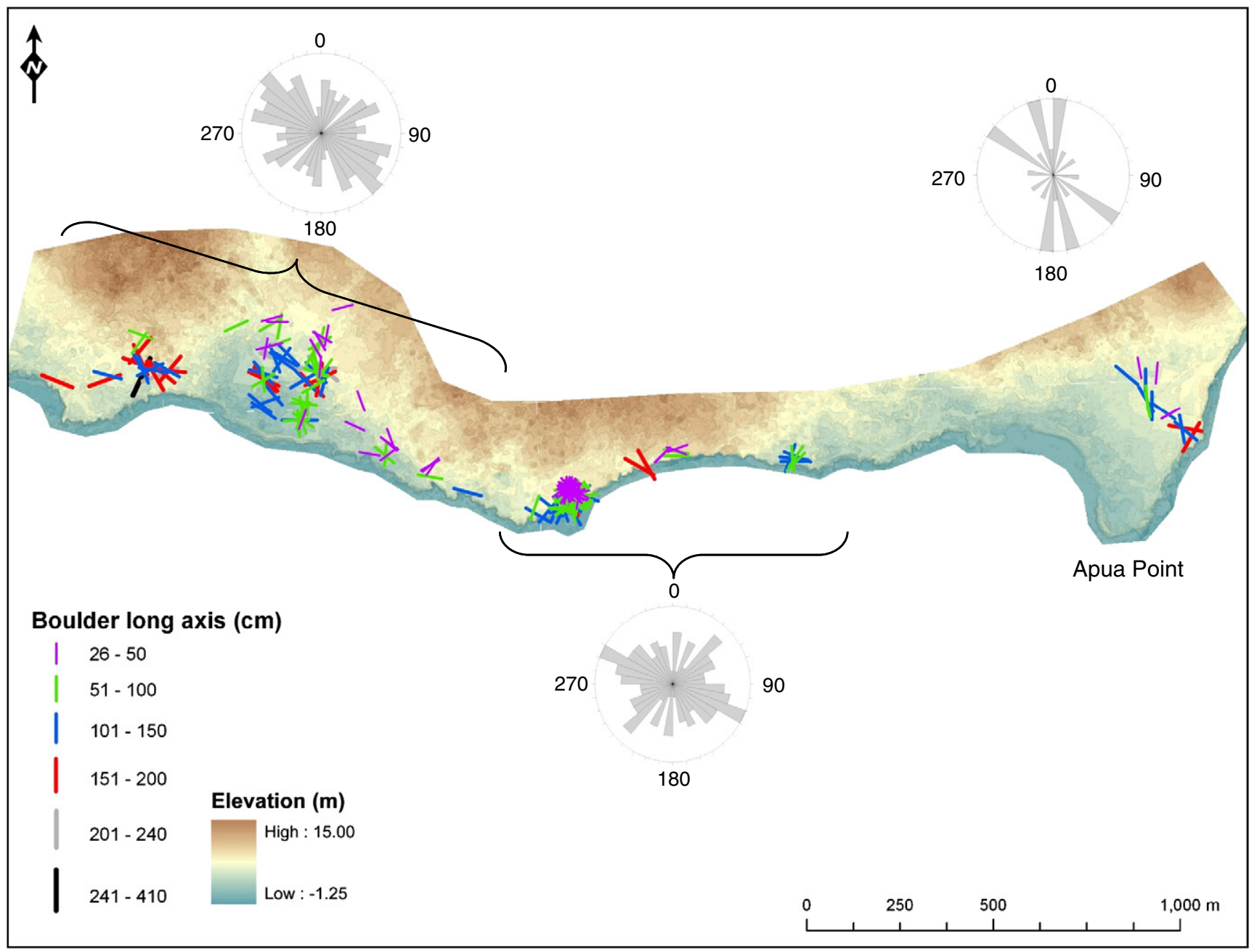

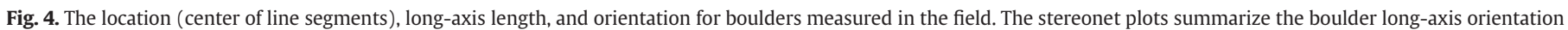
for three sub-areas (west, central, and east) of the study site. Base map is a lidar-derived false color map of the study area (lidar data courtesy of FEMA, 2007). 
by either low cliffs or a more gently sloping basalt ramp. Because the seaward edge of the terraces were frequently inundated by large waves they appear to be composed of relatively solid basalt where the weaker material has been removed by waves. In areas where the seaward edge of the terrace is either a very low cliff or forms a gently sloping ramp, intertidal beach deposits occur.

The basalt surface landward of the shoreline is composed of many features typical of a young volcanic landscape. Pahoehoe lava flows predominate in the study area and form an irregular and hummocky land surface with several to many meters of relief created by a patchwork of coalescing lava flows. Associated surface features include tumuli, cracks and fissures up to several meters in width, and kipuka. 'A'a type flows are relatively limited in the study area. The irregular surface relief most-likely controls flow over the land during marine inundation events by both channeling and diverging the flow of water resulting in a patchy distribution of sediment.

\subsection{Coastal deposits: coarse clasts}

Three coarse-clast deposit assemblages are recognized based on clast size, composition, angularity, orientation, packing, elevation and inland distance of the deposit. The three end-member deposit types are boulder-strewn gravel fields, ridge complexes, and cliff-top deposits. There is some natural gradation between the three deposit types. Fig. 4 shows the long-axis length and orientation for coarse clasts measured in the field and grouped by sub-region (west, central, and east). The west and east sub-regions have both boulder fields and ridge complexes, while the central region is made up mostly of clifftop deposits. Boulder long-axis orientation in the central and western sites are mostly organized shore parallel, whereas near Apua Point (eastern site) the boulders are mostly arranged perpendicular to shore although not necessarily perpendicular to flow directions because of the complex topography of the site and resultant wave refraction.

\subsubsection{Boulder-strewn gravel fields}

At Apua Point and in the western study area there occurs extensive boulder-strewn gravel fields comprised of isolated clasts and scattered pockets of concentrated clasts in topographic lows (Fig. 5). Individual clasts were observed up to $370 \mathrm{~m}$ inland, with the majority of the deposits occurring within $300 \mathrm{~m}$ of the shoreline. The deposits include isolated patches of thin sand sheets that tend to be more common near the shore and in topographic depressions. The boulders range in size up to nearly $4 \mathrm{~m}$ (a-axis) and consist mostly of angular to sub-angular clasts and occasional rounded particles. Most of the clasts (> 95\%) are composed of basalt fragments; however, there is scattered marine-derived material such as coral and shell debris. Isolated large clasts commonly appear stranded on topographic highs or wedged against obstacles such as tumuli or other basalt landscape features.

Fig. 6 shows a shore-normal lidar-derived topographic profile superimposed with a $10 \mathrm{~m}$-wide swath of boulder sizes (a-axis length) adjacent to the profile. The approximate boundaries between ridge deposits, and the younger 1973 Mauna Ulu lava flows and older basalt ( $350-500$ years) are also displayed in the figure. The largest clasts occur on the older flows, and at this location are concentrated in a zone about $150-200 \mathrm{~m}$ from the shoreline and well beyond the reach of storm waves. The inland deposits (i.e. non-coastal ridge) on the 1973 Mauna Ulu flows are most-likely deposited by the 1975 Kalapana tsunami, whereas the deposits on the older flows most-
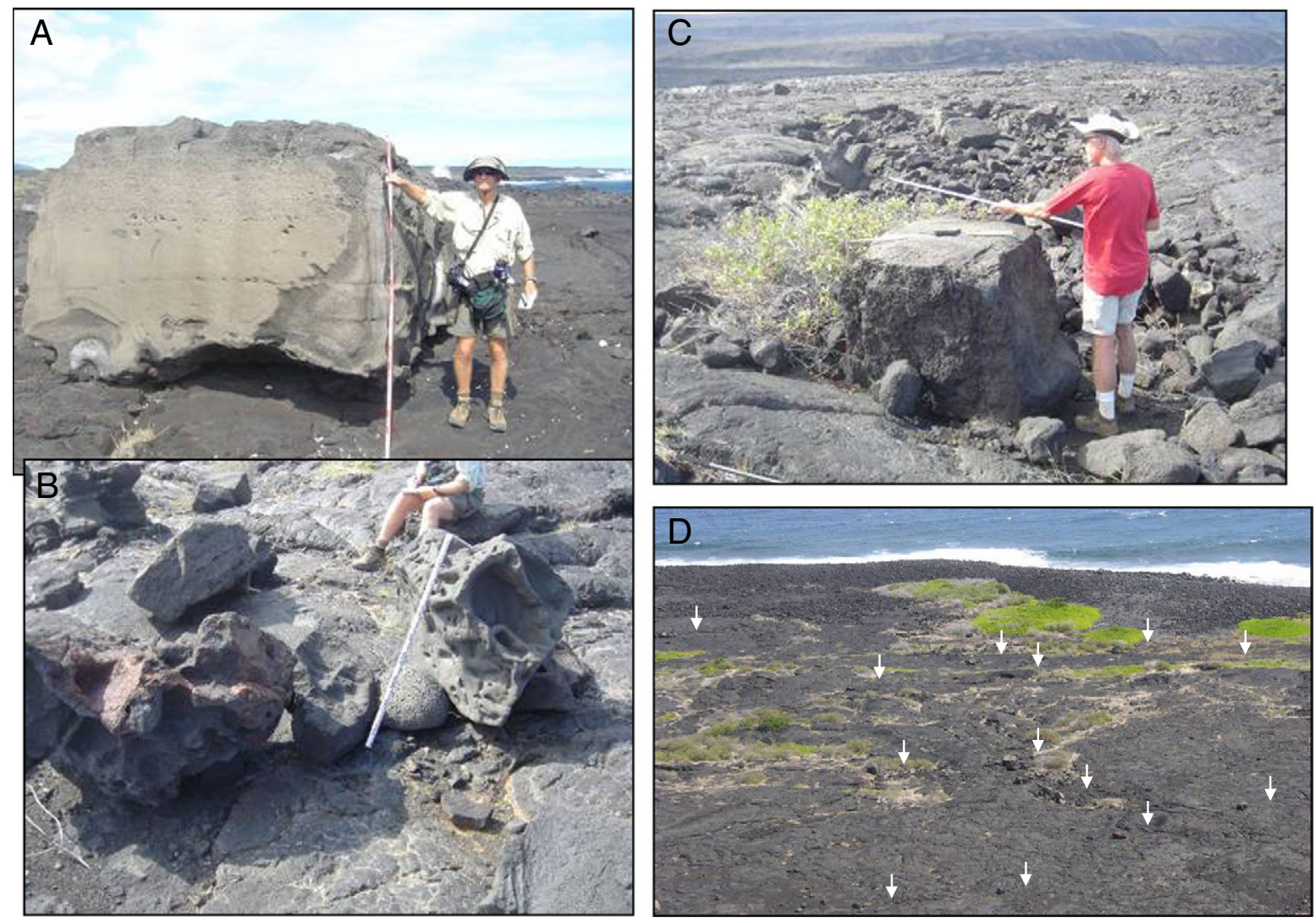

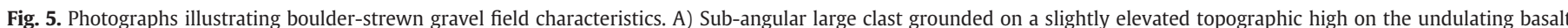

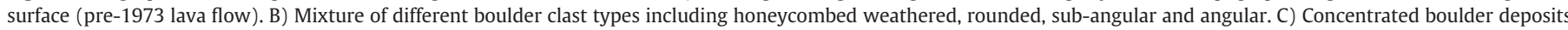

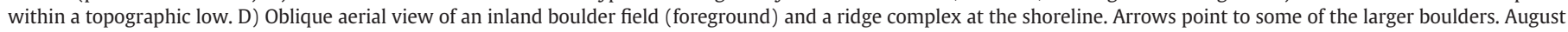
2007 photograph. 
A

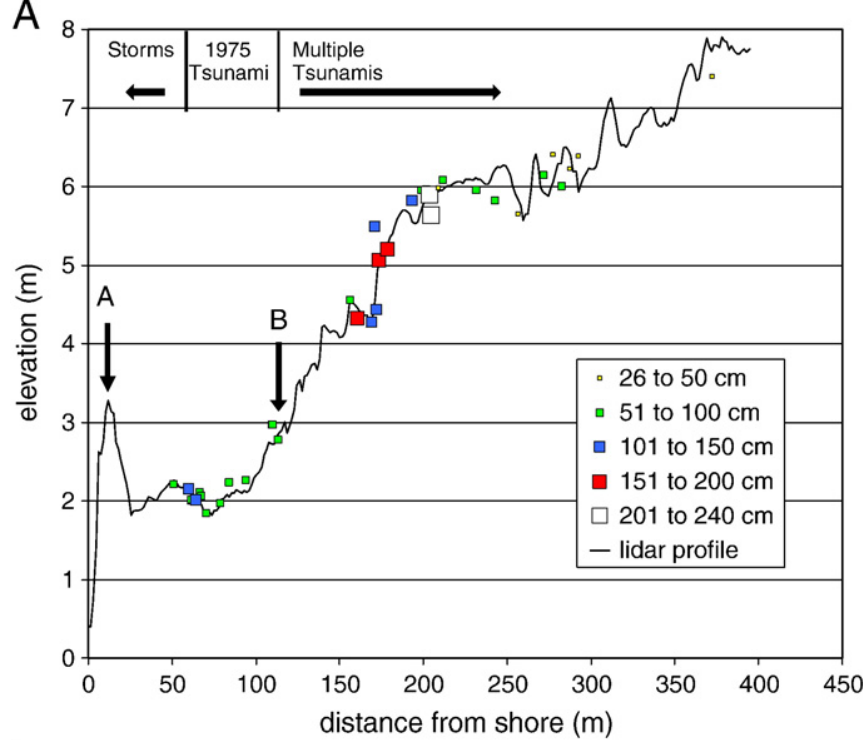

B

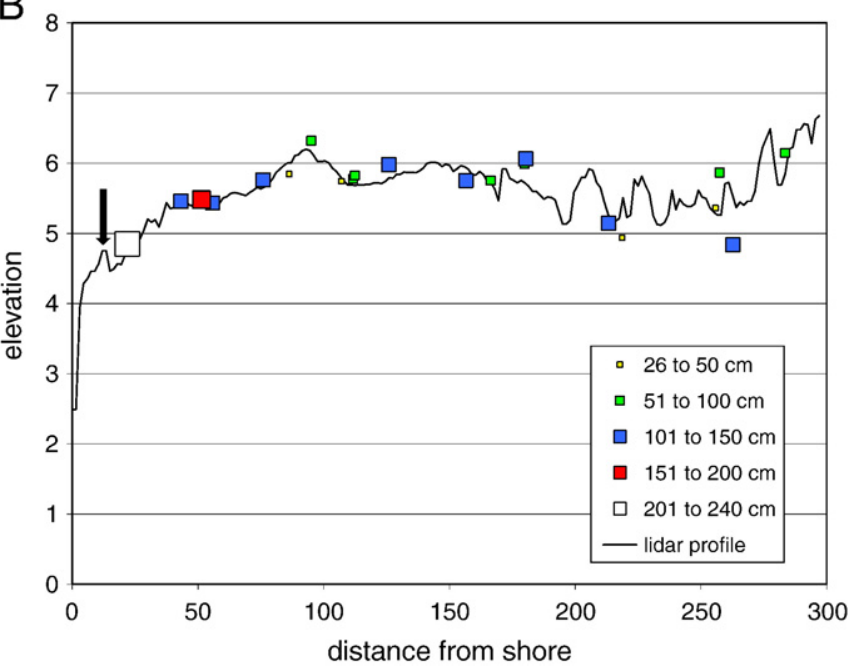

Fig. 6. A) Lidar-derived topographic profile and long-axis boulder length from clasts in an approximately $10 \mathrm{~m}$ wide swath parallel to profile 2 (see Fig. 2 for location). The "A" arrow points to the coastal ridge shown in Fig. 7. The "B" arrow is the approximate boundary between the 1973 Mauna Ulu lava flows (left of arrow) and older flows (right of arrow). The measured boulders shown in the figure are interpreted to be deposited by the 1975 tsunami (between the arrows) and by the 1975 tsunami and older events to the right of the right arrow. Not all boulders plot directly on the topographic profile because the profile is along a narrow swath $(\sim 1 \mathrm{~m})$ while the boulders are measured along a wider swath $(\sim 10 \mathrm{~m})$. The difference in elevation between the profile and the individual boulder measurements is an indication of the local variation in elevation. B) Lidar-derived topographic profile and long-axis boulder length from clasts in an approximately $10 \mathrm{~m}$ wide swath at Apua Point (see Fig. 2 for location). The basalt platform is composed of the older basalts therefore the boulders could be deposited from either the 1973,1868, or older events. The arrow points to a small boulder ridge at the coast.

likely are the product of multiple events including the 1975 and 1868 tsunamis. Fig. 6b shows a similar plot from Apua Point where all the boulders are deposited on older basalt and therefore can be the product of multiple tsunamis.

The source area for most of the boulder-sized clasts along cliffedcoast segments appears to be the upper seaward edge of the cliff as evidenced by angular to sub-angular clast rounding, general lack of marine indicators such as encrusting calcareous material, and occasional honeycomb weathered clasts. In the study area, honeycomb weathering is restricted to layers of relatively porous basalts exposed to salt spray on cliff faces. In rare instances there is a direct visual correlation between an individual clast and its source from a specific lithologic unit exposed in the cliff face. Clasts at the cliff base are rounded and covered with biologic encrustations - features that are rarely observed in boulder deposits landward of cliffs.

\subsubsection{Ridge complexes}

Shore-parallel ridge complexes occur either on low elevation basalt platforms ( 1-4 $\mathrm{m}$ asl) or as a supratidal extension of a pocket beach. Ridges on elevated platforms are typically set back from the cliff edge and separated from the seaward edge by a narrow sedimentfree zone. The ridges range in height from about 1 to $3 \mathrm{~m}$, are $10 \mathrm{~s}$ of $\mathrm{m}$ wide (Fig. 7), and composed mostly of basalt gravel and sand with smaller amounts of carbonate detritus. They are typically wedge shaped with a steep seaward face and a gentler landward slope, although steep landward-facing avalanche faces occur. Many of the ridges are bordered by sand sheets along their landward margin.

Ridge morphology and composition is related to shoreline orientation, substrate elevation, and availability of nearshore sediment. The best examples of well-developed shore-parallel ridges occurred on low elevation platforms along gently curving shorelines (Fig. 8). Short, segmented, and cuspate ridges are typical of higher platforms along irregular shorelines. Multiple low ridges that resemble beach berms are common.

In the study area ridge composition consists predominantly of basaltic sediment, although some areas have noticeably higher

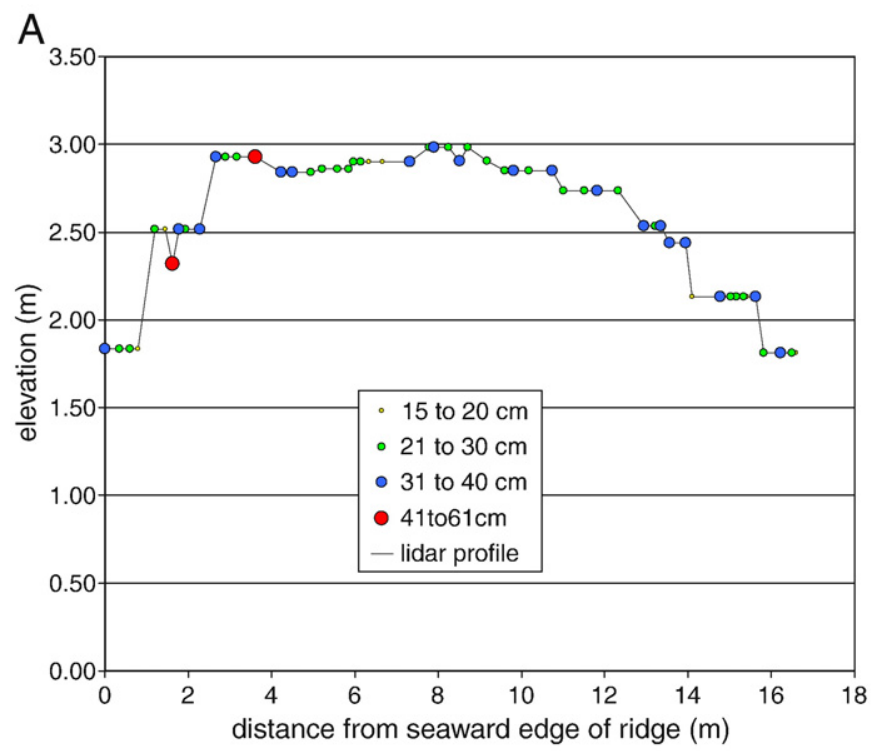

B

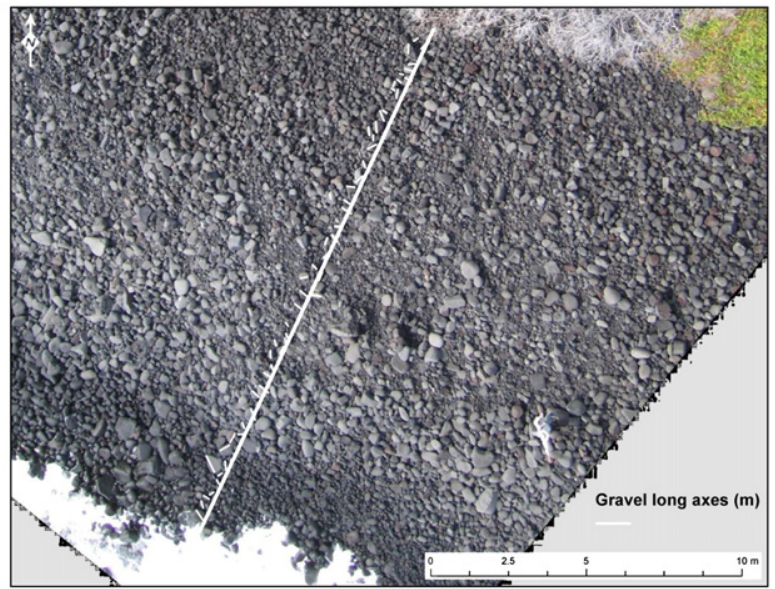

Fig. 7. A. Lidar-derived topographic profile (near profile 2 in Fig. 2 ) and gravel long-axis length for a ridge complex perched on a basalt terrace. B. Georectified kite camera image used to measure gravel long-axis length and orientation along the profile line shown in white. 

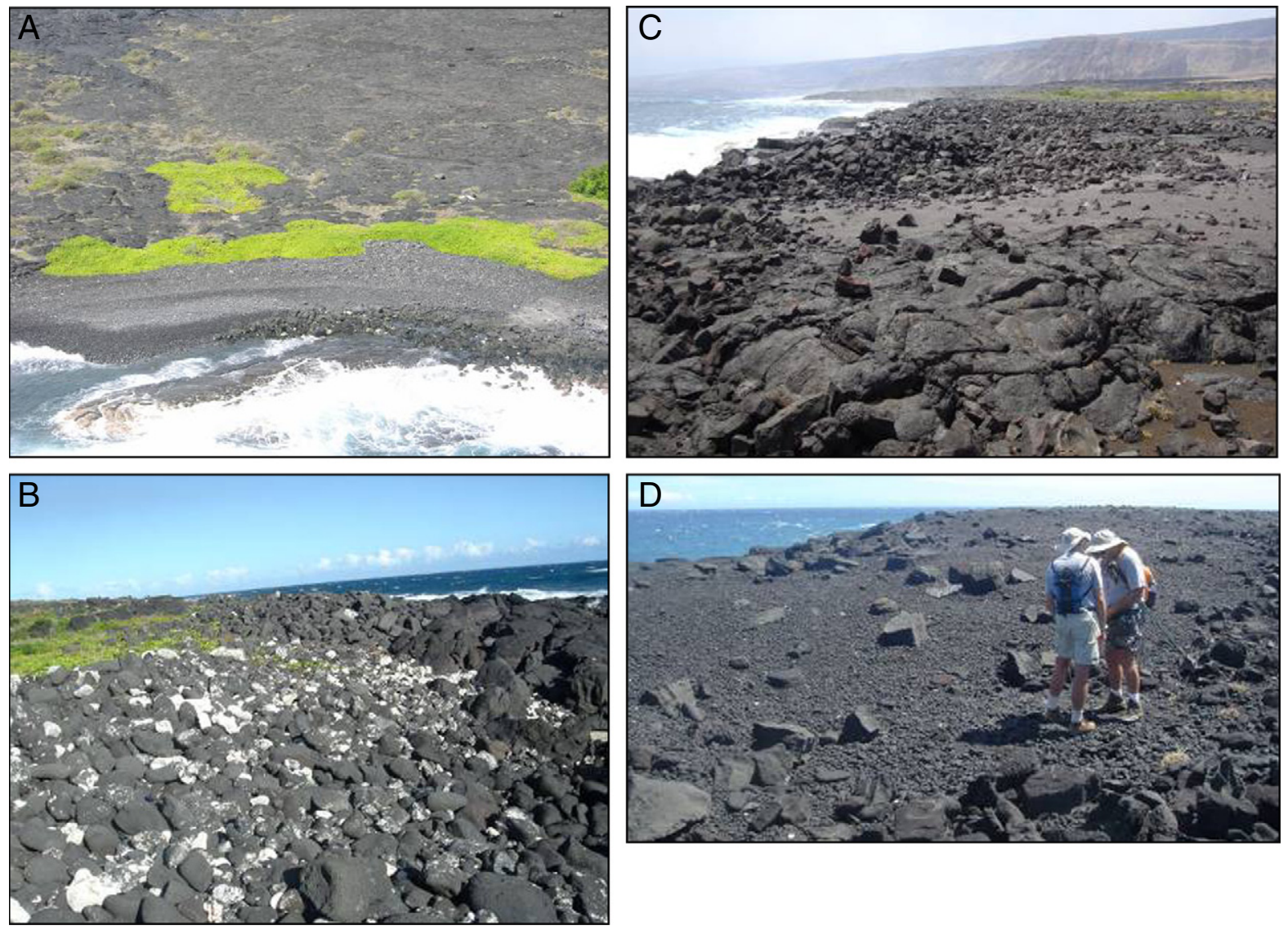

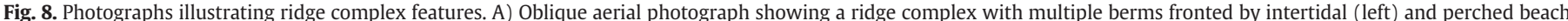

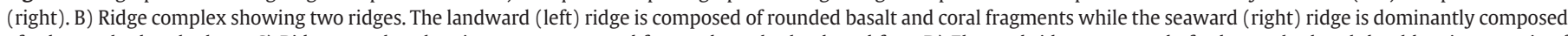

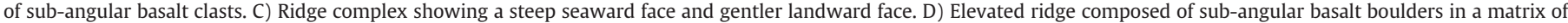
well-rounded basalt pebbles.

carbonate content. Sediment texture varies from sand through boulder sizes and ranges from well-sorted near-uniform size classes, to poorly sorted mixtures of sand and gravel. Particle rounding ranges from well-rounded to angular, however individual ridge berms tend to be composed of similarly rounded sediment. The coastal ridge complexes continue to accrete sediment on an annual basis.

\subsubsection{Cliff-top deposits}

Cliff-top deposits (CTDs) composed of mostly basalt gravel with smaller amounts of sand occur along sea cliffs that are typically higher than $5 \mathrm{~m}$ asl. The sediments extend from a narrow sediment-free zone at the edge of the cliff to 50 or more meters inland (Fig. 9) and appear to be derived mostly from the upper edge of the cliff face. Scattered gravel clasts are usually angular and sub-angular although rounded clasts are present in incipient ridges. The CTDs include characteristics of both ridge complexes and boulder-strewn fields such as: isolated coarse clasts, pockets of coarse clasts, thin sand sheets in topographic depressions, and incipient development of low ridges. Field evidence, including sand sheets and gravel size material, suggest that deposition occurred as a result of complete inundation of the basalt platform as opposed to splash deposition from wave impact on the cliff face. The best developed CTDs in the study area occur along the higher elevation cliffs mantled by the 1973 Mauna Ulu lava flows and therefore could be the product of either the 1975 Kalapana tsunami or large storm waves (Fig. 10).

\section{Discussion}

The southeast coast of Hawaici has been impacted by at least one recent tsunami (1975) and in many places by at least two tsunamis
(1975 and 1868). In addition, waves from southern swell, seasonal storms and the infrequent passing hurricane are high enough to flood the seaward edge of the basalt platform on a semi-annual basis (see Section 2.3; Table 1). Two primary differences between tsunami and storm wave characteristics are the frequency of occurrence and inland

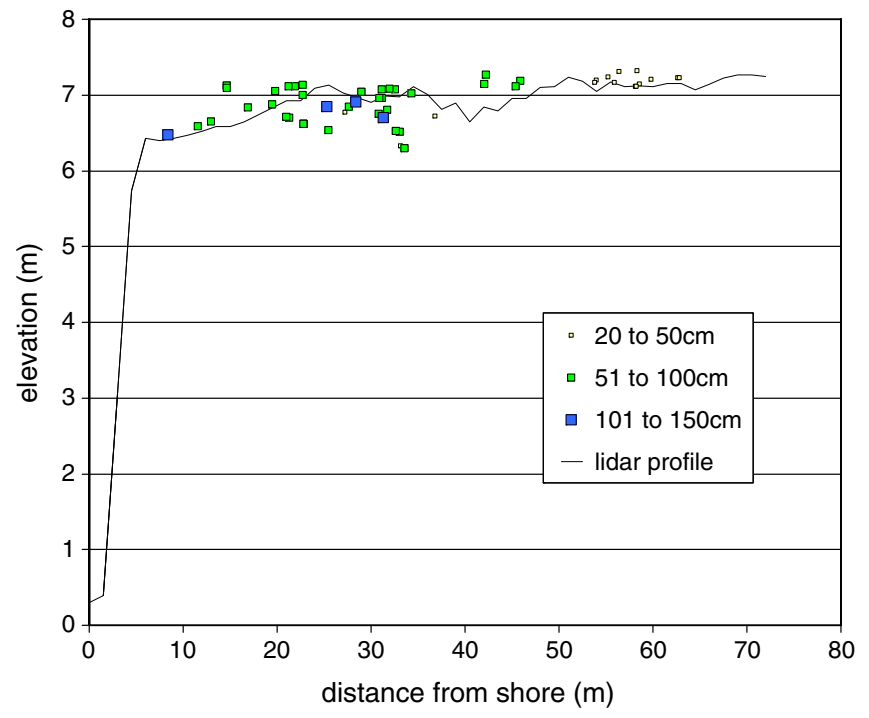

Fig. 9. Lidar-derived topographic profile and superimposed plot of boulder long-axis length for selected clasts along a $10 \mathrm{~m}$ wide swath parallel to the profile (near profile C3 in Fig. 2). Boulders that plot below the lidar profile are off line and in lower areas. 

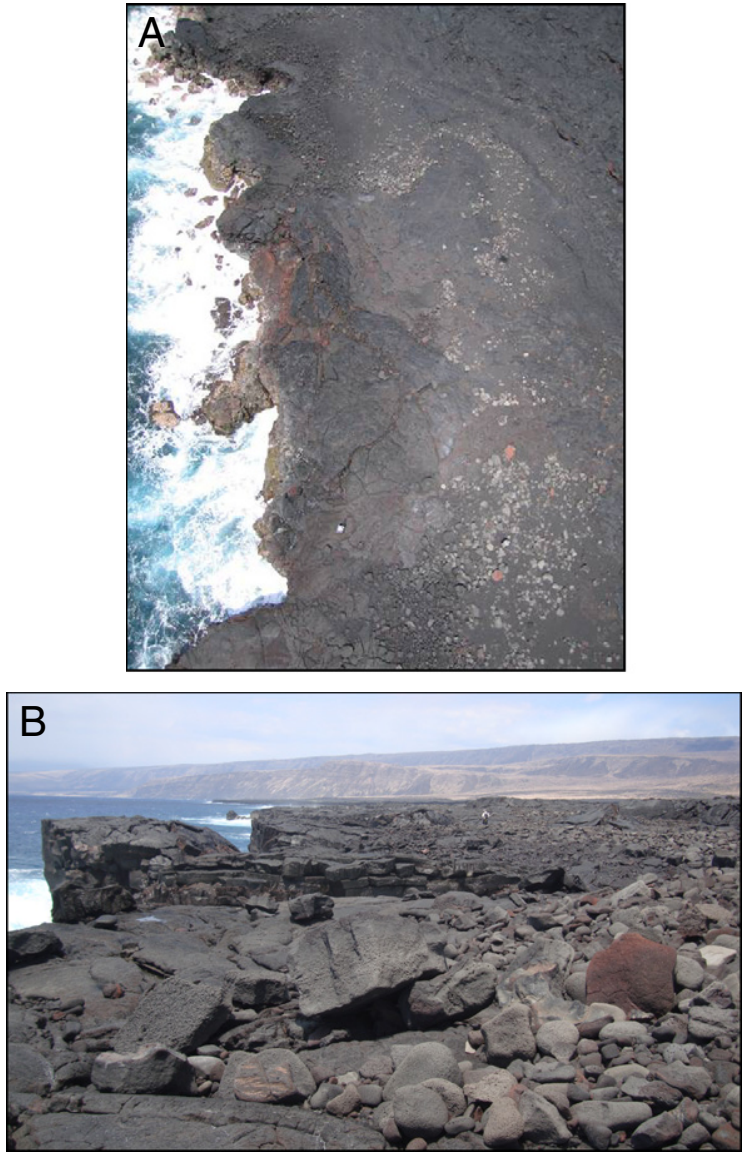
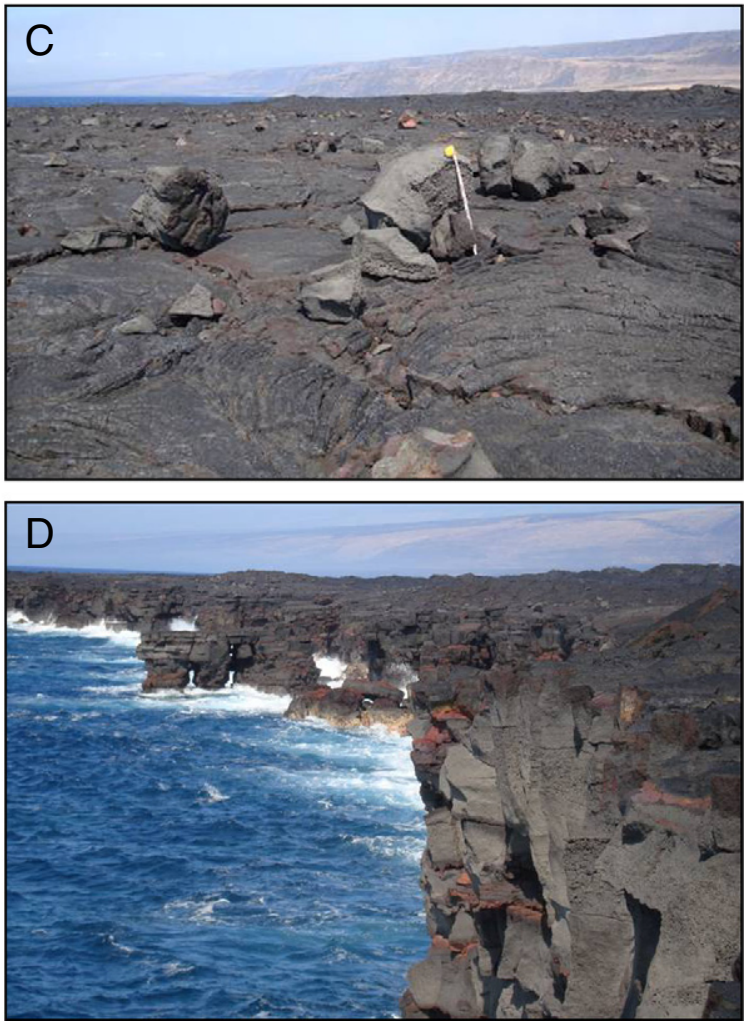

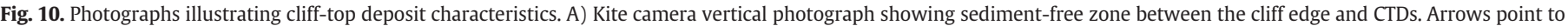

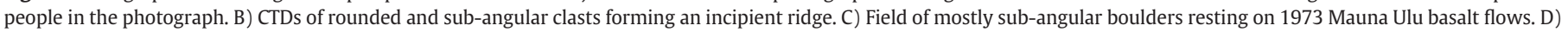
Cliff face showing basalt flow layering and fractures which are the source rocks for the CTDs.

distance of inundation (for a more complete list of differences see Switzer and Jones, 2008). Storm waves and the longer period large south swells are relatively frequent but their impact extends inland on the order of $50-100 \mathrm{~m}$ on the elevated platforms of the study area based on preliminary modeling studies and field observations from this study. In their study of the 1975 tsunami deposits at Halape and Apua Point, Goff et al. (2006) used $100 \mathrm{~m}$ from the shore as the maximum limit of storm-derived deposits. Tsunamis occur much less frequently but their impact extends much farther inland with inundation from two historical tsunamis extending more than $300 \mathrm{~m}$ (Goff et al., 2006; Tilling et al., 1976; Dudley and Lee, 1998). Therefore, in our study area, inundation distance serves as a good indicator for distinguishing between storm and tsunami deposits.

We also use deposit characteristics to discriminate between a storm and tsunami origin for deposits within our study site. In areas of tsunami inundation beyond the limit of storm inundation, boulder-strewn gravel fields are the characteristic deposit. Dispersed boulder deposits have been described from field studies of recent tsunamis in both intertidal (Goto et al., 2007) and coastal plain settings (Paris et al., 2009). The southeast Hawaici tsunami boulder fields are deposited on elevated basalt platforms in areas where the offshore profile is typically steep and there is little intertidal environment. Although the largest clasts $(>2.5 \mathrm{~m}$ a-axis) typically are deposited within the first $100 \mathrm{~m}$ from shore, there is no strong correlation between boulder size and either inland distance or elevation. Plots of boulder volume and a-axis length versus distance from shore show low correlation $\left(R^{2}=0.01\right.$ and 0.004 respectively). Many of the tsunami boulders are angular to sub-angular and are mostlikely plucked from the upper cliff face suggesting there is a limited supply of available large clasts for transport. Some infilling of shallow depressions occurs, but in general the tsunami deposits do not create large positive relief features.

Sediment is continually added to the coastal ridge complexes and the existing deposits are reworked regularly. Photographs from immediately after the 1975 tsunami and in 2007 of the same area show a bare basalt platform right after the tsunami and well-developed ridge complex in 2007 (Fig. 11). No coastal ridge was created by the tsunami, however subsequent storm waves combined with minor tectonic uplift $(<1 \mathrm{~m})$ were capable of building a significant ridge complex of predominately basalt boulders in less than 30 years. It is not known if a pre-existing ridge occurred at this location prior to the 1975 tsunami, but the rarity of rounded boulder clasts in the tsunami deposits suggest any pre-existing ridge was of limited extent. Where the coastline is gently curving the ridge complexes tend to exhibit a smooth and relatively uniform appearance. Ridges developed near highly irregular coastlines display a complex and irregular morphology. In all cases the ridges are positive relief features that bury and mask the irregularities of the underlying basalt platform surface.

Ridge complexes formed by storms on elevated volcanic platforms have recently been described from Iceland and have been attributed to deposition by storm waves (Etienne and Paris, 2010). The Reykjanes Peninsula deposits are more extensive, contain larger clasts, and extend further inland than the Hawaici deposits - this is most likely because of higher storm wave energy and a longer time period for ridge development in the Iceland deposits. The origin of ridge-complexes on elevated carbonate platforms in the Caribbean (Morton et al., 2008) that have strikingly similar morphological and textural characteristics to the Hawaici deposits, have also been attributed to deposition primarily by storm waves. 

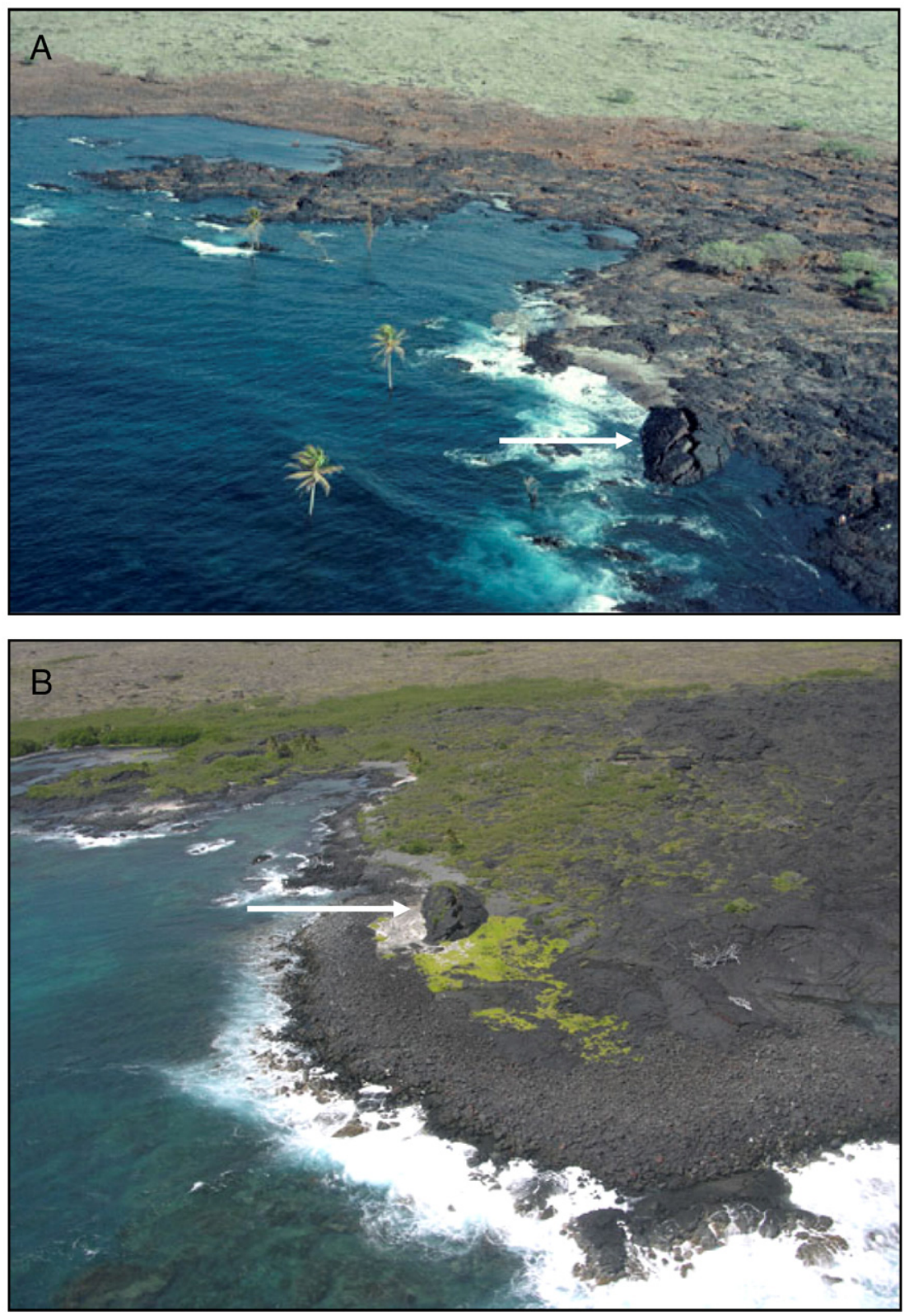

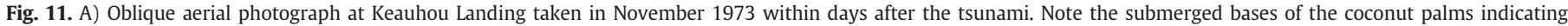

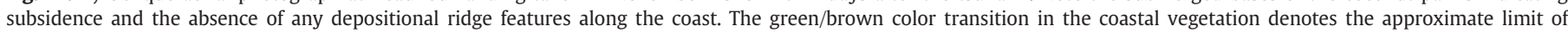

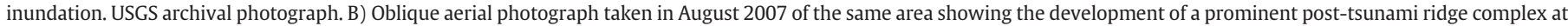
the shoreline. The arrow points to the same tumulus in both photographs. Vertical rebound of less than $1 \mathrm{~m}$ has occurred in the time interval between the photographs.

The CTDs exhibit characteristics of both tsunami and storm deposits. The CTDs coarse clasts don't extend as far inland as the other tsunami deposits, but this can be attributed to substantially higher elevations resulting in shorter inundation and sediment transport distances. The CTDs are well-developed on the 1973 Mauna Ulu basalts and therefore could be a product of the 1975 tsunami which reached runup heights of $\sim 14 \mathrm{~m}$ at Keauhou. However, CTDs of similar characteristics, but smaller clast size and extent, are present to the east of the study area near Kalapana village on early 1990 's basalt flow deposits at elevations greater than $5 \mathrm{~m}$. There is no known tsunami to have impacted this site since cliff formation in the early 1990's strongly indicating the CTDs are of storm-wave origin in this area. Storm-derived CTDs with similar characteristics to the Hawai'i deposits have been described elsewhere, most notably in Scotland and Ireland (Hall et al., 2006, 2008, and Hansom and Hall, 2009).

\section{Conclusions}

Deposits from two historical tsunamis on southeast Hawaici are identified on elevated basalt platforms. They are characterized by boulder-strewn gravel fields with large clasts and thin sediment accumulations with sheet-like sand and gravel deposits in topographic lows. These deposits extend inland over several hundred meters. Many of the clasts are angular to sub-angular and show little evidence of reworking or sorting. Most of the larger clasts appear to be derived from the upper seaward edge of the adjacent sea cliffs. Thickness of individual basalt flows and jointing patterns exert a strong control on potential clast size.

Deposits from large storm and/or swell waves in the same area are generally confined to within $50 \mathrm{~m}$ (100 m maximum) of the shoreline and are best characterized by prominent shore-parallel ridge complexes. Reworking, particle rounding, and addition of new material 
occur on a semi-regular basis during the passage of high wave events. These mixed sand and gravel deposits mask the underlying topography and create positive relief features that are regularly modified.

CTDs show a mixture of tsunami and storm deposit characteristics including isolated coarse clasts, pockets of coarse clasts, thin sand sheets in topographic depressions, and incipient development of low ridges. Near the study area they have formed on recent basalt flows that are younger than the 1975 tsunami demonstrating that tsunamis are not required for their formation. However, CTDs within the study are more extensive and better developed which may reflect either greater age and/or contribution of sediment from tsunami inundation.

\section{Acknowledgements}

Walter Dudley, John Coney, M.J. deMaintenon, and Genevieve Cain are gratefully acknowledged for introducing the authors to the deposits of the Halape Coast and assistance with field mapping in August 2007. Chip and Chase Fletcher assisted with the 2007 field survey, and Janet Watt assisted with field measurements in the August 2008 survey, their contributions are greatly appreciated. Staffs of Hawai'i Volcanoes National Park and the USGS Hawaiian Volcano Observatory were extremely helpful in logistics planning and support of field activities. Funding was provided by the USGS Coastal and Marine Geology Program.

\section{References}

Day, S.J., Watts, P., Grilli, S., Kirby, J.T., 2005. Mechanical models of the 1975 Kalapana, Hawai'i earthquake and tsunami. Marine Geology 215, 59-92.

Delaney, P.T., Denlinger, R.P., Lisowski, M., Miklius, A., Okubo, P., Okamura, A.T., Sako, M.K. 1998. Volcanic spreading at Kilauea, 1976-1996. Journal of Geophysical Research 103, $18,003-18,023$

Dudley, W.C., Lee, M., 1998. Tsunami!2nd Ed. University of Hawaii Press, Honolulu. 362 pp.

Etienne, S., Paris, R., 2010. Boulder accumulations related to storms on the south coast of the Reykjanes Peninsula (Iceland). Geomorphology 114, 55-70.

Goff, J., Dudley, W.C., deMaintenon, M.J., Cain, G., Coney, J.P., 2006. The largest local tsunami in 20th century Hawai'i. Marine Geology 226, 65-79.

Goto, K Chavanich, S.A. Imamura, F., Kunthasap, P., Matsui, T. Minoura, K., Sugawara D., Yanagisawa, H., 2007. Distribution, origin, and transport process of boulders deposited by the 2004 Indian Ocean tsunami at Pakarang Cape, Thailand. Sedimentary Geology 202, 821-837.

Goto, K., Okada, K., Imamura, F., 2009. Characteristics and hydrodynamics of boulders transported by storm waves at Kudaka Islands, Japan. Marine Geology 262, 14-24.
Hall, A.M., Hansom, J.D., Williams, D.M., Jarvis, J., 2006. Distribution, geomorphology and lithofacies of cliff-top storm deposits: examples from the high-energy coasts of Scotland and Ireland. Marine Geology 232, 131-155.

Hall, A.M., Hansom, J.D., Jarvis, J., 2008. Processes, patterns and rates of erosion by storm waves on hard rock headlands: the Grind of the Navir, Shetland, Scotland. Marine Geology 248, 28-46.

Hansom, J.D., Hall, A.M., 2009. Magnitude and frequency of extra-tropical North Atlantic cyclones: a chronology from cliff-top deposits. Quaternary International 195, 42-52.

Holcomb, R.T., 1987. Eruptive history and long-term behavior of Kilauea Volcano. In: Decker, R.W., Wright, T.L., Stauffer, P.H. (Eds.), Volcanism in Hawai'i: U.S. Geological Survey Professional Paper 1350, 1, pp. 261-350. chapter 12 of.

Lander, J.F., Lockridge, P.A., 1989. United States tsunamis (including United States possessions) 1690-1988. U.S. Department of Commerce, NOAA, National Environmental Satellite, Data, and Information Service, NGDC, Boulder, Colorado. 265 pp.

McMurtry, G.M., Fryer, G.J., Tappin, D.R., Wilkinson, I.P., Williams, M., Fietzke, J., GarbeSchoenberg, D., Watts, P., 2004. Megatsunami deposits on Kohala volcano, Hawai'i, from flank collapse of Mauna Loa. Geology 32, 741-744.

Morton, R.A., Gelfenbaum, G., Jaffe, B.E., 2007. Physical criteria for distinguishing sandy tsunami and storm deposits using modern examples. Sedimentary Geology 200, 184-207.

Morton, R.A., Richmond, B.M., Jaffe, B.E., Gelfenbaum, G., 2008. Coarse-clast ridge complexes of the Caribbean: a preliminary basis for distinguishing tsunami and storm-wave origins. Journal of Sedimentary Research 78, 624-637.

Owen, S., Segall, P., Lisowski, M., Miklius, A., Denlinger, R.P., Sako, M., 2000. Rapid deformation of Kilauea Volcano: Global Positioning System measurements between 1990 and 1996. Journal of Geophysical Research 105, 18,983-18,998.

Paris, R., Wassmer, P., Sartohadi, J., Lavigne, F., Barthomeuf, B., Desgages, E., Grancher, D., Baumert, P., Vautier, F., Brunstein, D., Gomez, C., 2009. Tsunamis as geomorphic crises: lessons from the December 26, 2004 tsunami in Lhok Nga, West Banda Aceh (Sumatra, Indonesia). Geomorphology 104, 59-72.

Scheffers, A., 2005. Coastal response to extreme wave events - hurricanes and tsunami on Bonaire. Essener Geographische Arbeiten 37100 pp.

Scheffers, S.R., Haviser, J., Browne, T., Scheffers, A., 2009. Tsunamis, hurricanes, the demise of coral reefs and shifts in pre-historic human populations in the Caribbean. Quaternary International 195, 69-87.

Sherrod, D.R., Sinton, J.M., Watkins, S.E., Brunet, K.M., 2007. Geologic Map of the State of Hawai'i. U.S. Geological Survey Open-File Report 2007-1089 (last accessed 09/18/ 2009: http://pubs.usgs.gov/of/2007/1089/)

Switzer, A.D., Burston, J.M., 2010. Competing mechanisms for boulder deposition on the southeast Australian coast. Geomorphology 114, 42-54.

Switzer, A.D., Jones, B.G., 2008. Large-scale washover sedimentation in a freshwater lagoon from the southeast Australian coast: sea-level change, tsunami, or exceptionally large storm? Holocene 18, 787-803.

Tilling, R.I., Koyanagi, R.Y., Lipman, P.W., Lockwood, J.P., Moore, J.G., Swanson, D.A., 1976. Earthquake and related catastrophic events, island of Hawai i, November 29, 1975. A preliminary report. U.S. Geological Survey Circular, 740. 33 pp.

Walker, D.A., 1994. Tsunami Facts. SOEST Technical Report 94-03. University of Hawaici, Honolulu. 91 pp.

Wolfe, E.W. and Morris, J. (compilers), 1996. Geologic Map of the Island of Hawai'i. U.S. Geological Survey, Misc. Investigations Series Map I-1-2524-A. 